\title{
Defining the Role Engagement of Small and Medium-Sized Enterprises (SMEs) in Corporate Social Responsibility (CSR)
}

\author{
Benjamin James Inyang ${ }^{1}$ \\ ${ }^{1}$ Department of Business Management, University of Calabar, Calabar, Nigeria \\ Correspondence: Benjamin James Inyang, Department of Business Management, University of Calabar, Calabar, \\ Nigeria. Tel: 234-803-377-3403. Email: benji1955.uincal@yahoo.co.uk
}

Received: February 17, 2013

Accepted: March 21, 2013

Online Published: April 17, 2013

doi:10.5539/ibr.v6n5p123

URL: http://dx.doi.org/10.5539/ibr.v6n5p123

\begin{abstract}
Corporate social responsibility (CSR) discourse, academic research, public policy and media commentaries, which have burgeoned in the past few decades in response to the desire to define the nexus between business and society tended to focus mainly on large corporate organizations which are expected to behave responsibly. The big businesses have for years attracted large volume of literature on CSR. Very little literature is currently available to enhance our understanding about the engagement of small- and medium-sized enterprises (SMEs) in CSR. The SMEs, often defined variously, in terms of turnover, gross asset value, ownership structure and the number of employees, is a significant sector worldwide in terms of economic, environmental and the social impact they make. This paper attempted to bridge this apparent research gulf, defined the nature of SMEs, the aggregate contributions of the sector to economies of both developed and developing nations and their role engagement in CSR. The study adopted qualitative literature survey method. A review of the paltry literature provided insight and defined the direction of research in this important and underexplored area of study. SMEs were found to perform roles associated with community development, employee initiatives, consumerism, environmental actions and supply chain requirements. To overcome the constraints confronting SMEs engagement in CSR initiatives the paper recommended increased resources, training programmes, development of SMEs-oriented tools and standards to guide adoption and implementation, and government intervention strategies to create the necessary incentives and support services for effective engagement.
\end{abstract}

Keywords: corporate social responsibility, small and medium-sized enterprises, responsible practices, corporate citizenship

\section{Introduction}

The concept of corporate social responsibility (CSR) has since its formal emergence through the seminal work of Bowen (1953) on the social responsibility of business generated serious interest and concern among a large spectrum of the people, the academics, corporate planners, the society at large, etc. The evolutionary history of the concept has been firmly rooted in large corporate organizations. Sahlin-Anderson (2005:595) considers CSR "as a global trend incorporating business corporations, states, international organizations and civil society organizations". Thus, CSR discourse, academic research, public policy and media commentaries, which have burgeoned in the past few decades in response to the desire to define the nexus between business and society tended to focus mainly on large corporate, organizations which are expected to behave responsibly.

The society expects the business organizations to undertake CSR, that goes beyond the legal obligation and profit maximization to include economic, environmental sustainability and social development. The big businesses have therefore attracted a considerable large volume of literature. Very little literature is currently available to enhance our understanding about the engagement of small and medium sized enterprises (SMEs) in CSR. The SMEs, another important form of business organization and which is often defined variously, in terms of turnover, gross asset value, ownership structure and the number of employees, is a significant sector worldwide in terms of economic, environmental and social impact they make. SMEs account for more than $90 \%$ of the world's business enterprises.

The business organization of any form - large or small is seen as a creation of society and whose survival is dependent on the very society. The society in turn apparently seems to impose certain responsibilities or obligations on the business organization to discharge. Thus CRS involves a complex range of activities that the 
business enterprise is expected to undertake to satisfy the interest of multiple stakeholders and maintain harmonious relationship with the community where the business is located. Business enterprises are usually regarded as constructive partners in the communities of operation. They have been instrumental in creating employment opportunities, wealth, products and services, yet the pressure on business to play a role in social issues involving, stakeholders - employees, society, environment and government is increasing (Sharma, Sharma \& Devi, 2009).

The World Business Council for sustainable development writes that businesses are integral parts of society and their roles are encouraged by the society; the two are interdependent and must ensure mutual understanding and responsible behaviour (WBCSD, 2009). Similarly, Porter and Kramer (2006) add that successful organizations need a healthy society at the same time a healthy society needs successful companies. There is justification to then study the role engagement of SMEs in CSR as is the case with the large volume of literature which is focused on large corporations and since the society also has expectations of SMEs to behave responsibly.

The objective of this study is to bridge the apparent research gulf existing between the two economic sectors big corporate organizations and SMEs in terms of CSR discourse and academic research. The study further defines the nature of SMEs and their engagement in responsible practices, analyses the factors driving these initiatives, the strategies of engagement and challenges of implementation as well as defines the action plan to overcome these constraints to guide effective implementation.

The paper is divided into eleven sections: The introductory section is followed by the literature review while section three states the methodology of study. Section four analysizes the contributions of the SMEs to economic development. Section five and six handle the emerging concern about SMEs-CSR discourse and the motivations for SMEs engagement in CSR respectively. Section seven presents the strategies of engagement while section eight identifies the benefits of engagement. The challenges of implementation and the strategies to overcome them are discussed in sections nine and ten respectively. This is followed by the conclusion.

\section{Literature Review and Definition of Concepts}

\subsection{Corporate Socials Responsibility}

There is no agreement in the literature about the definition of CSR as scholars are wont to offer definitions which vary in content, context, process and value. Industry Canada (2009:1) declares that "CRS is an evolving concept that currently does not have a universally accepted definition”. Meehan, Meehan and Richards (2006) similarly note that definitional issues regarding CSR have remained an area of deliberation from the concept's very beginnings. These and many similar declarations are well supported by many reviews and scholarly writings which have attempted to define the concept of CSR (Carroll, 1979; 1999; Wood, 1991; Van Marrewijk, 2003; Catalysts Consortium, 2002; McWilliams, Siegal \& Wright, 2006; Obalola, 2008; Dahlsrud, 2008).

Davis and Blomstroom (1975:39) consider CSR as "obligations of decision makers to take actions which protect and improve the welfare of society as a whole along with their own interest”. This definition implies that CSR seeks to protect and improve society and thus bringing positive benefits to society. Another point is that CSR is an obligation. Carroll (1979:500) defines CSR thus: "The social responsibility of business encompasses the economic, legal, ethical and discretionary expectations that society has of organization at a given point in time". Carroll's four dimensional definition of CSR involves the conduct of a business so that it is economically profitable, law abiding, ethically oriented and socially supportive. The discretionary dimension involves voluntarism and or philanthropy. The World Business Council for Sustainable Development (WBSCD 2009:2) defines CSR as "the commitment of business to contribute to sustainable economic development, working with employees, their families, the local community and society at large to improve their quality of life". For Industry Canada (2007:1) CSR is "the way firms integrate social, environmental and economic concerns with their values, culture, decision making, strategy and operations in a transparent and accountable manner and thereby establish better practices within the firm, create wealth and improve society".

According to EU Commission (2002, 347 final:5) “.... CSR is a concept whereby companies integrate social and environmental concerns in their business operations and in their interaction with their stakeholders on a voluntary basis". In his contribution Freisleben (2011:53) states that "CSR is about the company having an ethos or set of values - sometimes expressed in the vision, mission and goals of the organization and many business practices to produce an overall positive impact on society". In a review of the literature, Liu and Fong (2010:35) note that "CSR is largely understood as a range of voluntary initiatives, beyond legal and contractual requirements, which, if undertaken effectively should eventually benefit the workforce, their families and local communities and ultimately improve the overall welfare of the community and contribute to economic development". Inyang, Awa and Enuoh (2011:120) define CSR as "obligation of businessmen to pursue those 
policies, to make those decisions to follow those lines of action, which are desirable in terms of objectives and values to the society of their location". This is a useful definition that is elastic enough to accommodate the varied concerns of CSR as exposed in the burgeoning literature. Issues of economic profitability; legal concern; ethical and philanthropic activities; sustainability in all its ramifications; and ecological, social etc., economic accountability - where businessmen invest in projects that have specific effect on the community and are profitable to the firm and its stakeholders can be accommodated in the definition. Equally, important is the fact that content, context, cross-cultural, and/or country specific analysis concerned with CSR can be undertaken successfully and more objectively.

\subsection{Small and Medium-Sized Enterprises (SMEs)}

Like CSR the concept of SMEs is not amenable to a universally accepted definition. The definition of SMEs varies in context across countries, industries, organizations, agencies and the academic community. SMEs are often defined numerically or specifically to cover companies with a workforce ranging from 1 to 100 employees and in some cases up to 250 employees as the upper limit. When they are statistically defined the lower limit for the member of employees for the "small scale enterprises" is usually put at between 5-10 workers with and upper limit of 50-100. The upper limit for the "medium-sized enterprises" is usually 100-250 employees. The European Union Standard definition for SMEs is any business with fewer than 250 employees and a turnover of up to 50 million Euros and a balance sheet of about 43 million Euros. This definition may not be applicable to all countries since SMEs considered large in one country may not be so in another. The foregoing therefore shows that SMEs encompass a very broad range of enterprises from established traditional family business employing over a hundred people to survivalist self-employed people working in informal microenterprises.

Small and medium-sized enterprises are also defined in terms of qualitative criteria such as controlling a small share market, personal management by owner, or even lacking a formalized bureaucratic structure. The SMEs are therefore distinguished from larger companies by such characteristics as owner-managed, independent, multitasking, fire-fighting, cash limited, personal relationships and informality. Spence and Lozano (2000) note that SMEs are majorly oriented toward solving day-to-day problems; there is also the dominance of informal relations, interpersonal relations and communication. Enderle (2004) adds that there is a high degree of interrelation with their environment or community of operation and the SMEs are subject to the market dynamics which are determined by large enterprises through the supply chain. Lepoutre and Heene (2006:259) present an interesting definition of SMEs in terms of a small business responsibility, where a responsible entrepreneur is a person who:

- Treats customers, business partners and competitors with fairness and honesty.

- Cares about health, safety and general well-being of employees and customers.

- Motivates the workforce by offering training and development opportunities.

- Acts as a "good citizen" in the local community.

- Is respectful of natural resources and the environment.

These characteristics directly influence or affect the way in which SMEs engage in CSR. The orientation of the small business owner tended to be employee, customer and community focus and CSR initiatives are accordingly designed to satisfy these stakeholders.

\section{Methodology of Study}

The study adopted qualitative literature survey method. This facilitates in-depth and contextual analysis of issues under study. A review of the paltry literature provided useful insight about the significant position of SMEs engagement in CSR. This methodology also provided the basis for defining the direction of research in this important and apparently underexplored area of study.

\section{Contribution of SMEs to Economic Development}

The SMEs make significant contribution to the economies of both developed and developing nations in terms of employment generation and development impacts. The European Union Commission Report of 2005 notes that SMEs contribute greatly to the economy of Europe; 99\% of all companies are SMEs and they provide around 75 million jobs and in some industries like in textile, construction and furniture, they provide around $80 \%$ of the job. In the United States small businesses represent more than $99 \%$ of all employees, engaging $52 \%$ of private sector employees (www.sba.gov). Princic (2003) reports that the SMEs comprise approximately $90 \%$ of Canadian business and employ almost half of the Canadian workforce. The National Development Reform Commission of China reports that SMEs contribute considerably to income growth, employment growth, export 
expansion and economic structure optimization. It further stated that until 2006, SMEs amounted to 45\% of employment in townships and 60\% of the Gross Domestic Product of China. In South Africa, SMEs account for about $91 \%$ of the formal business entities, contributing to about $57 \%$ of GDP and providing almost $60 \%$ of employment (Kongolo, 2010). The Asian Association of Management Organization in its report of 2007 notes that SMEs in the Asia-Pacific region remain a critical source of employment and income creation contributing more than $60 \%$ of jobs. The Australian Bureau of Statistics 2007 notes that the SMEs, which are made up of firms with less than 200 employees, account for $95 \%$ of all Australian commercial organizations. These figures are similar to what is obtained in developing countries. Luetkenhorst (2003), notes that SMEs constitute $90 \%$ of enterprises and account for at least half of employment in developing countries. Overall, SMEs are known to constitute more than $90 \%$ of business worldwide and account for between $50 \%$ and $60 \%$ of employment and more than half of gross domestic product.

The engagement of SMEs in CSR is very important in the economy since these enterprises help to create employment opportunities, drive economic growth, promote private sector development and provide opportunity for equitable distribution of income in scoeity. Luetkenhorst (2004:159) argues that SMEs support economic growth and livelihoods in developing countries because these enterprises:

1) Tend to use more labour-intensive production processes than larger enterprises, thus boosting employment leading to more equitable income distribution.

2) Provide livelihood opportunities through simple, value-adding processing activities in agriculturally based economies.

3) Nurture entrepreneurship.

4) Support building up of systematic productive capacities and the creation of resilient economic systems, through linkages between small and large enterprises.

Studies undertaken within the African context provide support for SMEs been instruments of social transformation of the rural communities through their social responsibility actions (Dzansi, 2011; Oguntade \& Mafimisehi, 2011; Viviers \& Venter, 2007). The SMEs in this context offer opportunities for capacity building, economic empowerment and provision of rural infrastructure.

Studies conducted about SMEs in Nigeria - a developing country, for example, have noted the promotion of entrepreneurship among SMEs by contributing significantly to tackling unemployment (Owualah, 1999). The SMEs help to drive national development like the cases in developed economies (Safiriyu \& Njogo, 2012). Aremu and Adeyemi (2010) found that SMEs have gained prominence as seed beds of innovations, inventions and employment generation. Owualah and Obokoh (2007) found that introducing enterprise training in educational institutions in the Niger Delta region of Nigeria enhanced the development of entrepreneurship and entrepreneurial skills and helped to change the mind set of youths to venture into SMEs operations after graduation rather than hostage-taking or kidnapping to extract ransoms. The close relations of the SMEs operators with employees, the local community and business partners often mean they have a naturally responsible approach to business. The SMEs are, in fact, no less responsible than large enterprises.

\section{Emerging Interest in SMEs-CSR Discourse}

The recent awakening of interest among scholars and the research community to engage in SMEs-CSR discourse is as a result of the realization of the aggregate impacts of SMEs on national economies. The burgeoning research focuses on embedding CSR in SMEs and the challenges confronting these businesses as they handle social issues in response to society's expectations and pressures. A major development of note appears in the special issues on CSR in SMEs published by Business Ethics: A European Review, 18(1) Journal 2009 and Journal of Business Ethics, 67(3) in 2006. International Business Research, 5(7) 2012 in its special issue on CSR and SMB published by Canadian Centre of Science and Education emphasizes the same theme. These studies highlight the different ways CSR is gradually emerging not only as a condition but also as a strategy for SMEs. Kechiche and Soparnot (2012), note that the SMEs consider CSR not as an add-on but rather as a part of the overall day-to-day management. Santos (2011) in a study conducted to gain an insight into SMEs-CSR practices in Portugal finds that while CSR takes on an informal, non-structured character, it was incorporated into the daily management of the companies studied. The recent call for papers by Business and Society with the proposed special issue on "SMEs and CSR in developing countries: Advancing Academic and Policy-oriented knowledge" to be published in June 2013 is to provide new perspectives and insights on CSR and SMEs in developing countries.

These commendable developments have helped to increase the number of research works on the nexus between 
SMEs and CSR even though the output still falls short of the large volume of literature on CSR which traditionally focused on larger firms. The emerging literature on the engagement of SMEs in CSR is encouraging and pointing to the need for more research to unearth the unique characteristics of SMEs that predispose them to undertake CSR initiatives. Much of the literature pertaining to large organizations appears to have little relevance to SMEs as a rather different set of meachnisms are in play when SMEs decide on how responsible they should behave (Fitjar, 2011). Russo and Perrini (2010), note that the idiosyncrasies of large firms and SMEs explain the different approaches to CSR. Spence (2007) notes the following characteristics which help to understand and distinguish CSR policies in SMEs from large firms:

1) A lack of codification of CSR in SMEs.

2) Personal motivations prevails on other motivations such as marketing approach and strategic or public relations - approaches for engaging in social responsibility activities.

3) The owner-manager is primarily responsible to develop and implement CSR activities..

4) The embeddedness of the firm in local communities affects the choice of the firm to focus on socially responsible behaviour.

5) The importance of social capital and informal relationships for the success of the firms - which is closely linked to their reputation - represents an important input to act with honesty and integrity.

6) The central role assumed by human resources in small firms generates a high commitment of the organizations in employees and their families.

7) The industries in which the SMEs operate directly affect their approach on how CSR activities are handled.

\section{Motivations or Drivers for SMEs Engagement in CSR}

There are several motivating factors or drivers responsible for SMEs engagement in CSR. The drivers are conceptualized as the internal and external pressures that aid, promote and compel SMEs to identify with, engage and implement CSR programmes. The internal and external drivers to SMEs social performance are based on internal decision making autonomy and external market pressure respectively (Kusyk \& Lozano, 2007).

In the class of internal motivations or drivers for engagement in responsible activities are the following:

1) The manager's personal values or ethical orientation and level of morality play a major role in determining his level of commitment to the implementation of social responsibility programmes in the enterprise. The emerging literature provides support for this factor (Vives, 2006; Vives 2009; Leopoutre \& Heene, 2006; Hsu \& Cheng, 2011; Freisleben, 2011).

2) The engagement is purely based on "normative case" where SMEs see it as the "right thing to do" to give back something to the community of business location. This is the desire or need to be good citizen in the community.

3) The "business case" is also important where the enterprises anticipate gaining benefits from community engagement or philanthropy. Such benefits may be improved community image, better business returns and improved customer loyalty.

4) The strong identification with the community also provides driving force for SMEs engagement CSR.

The external pressures that compel SMEs to engage in CSR are:

1) The supply chain pressure from large organizations helps the SMEs to adopt ethically responsible practices to sustain their business relationship with such big firms.

2) Community pressure - the local media and non-governmental organizations and community-based organizations often bring pressure to SMEs to handle the issues of social performance.

3) The need to obey laws and regulations and avoid sanction and negative publicity is another driver compelling SMEs to undertake CSR.

4) The issue of customer loyalty is also important. The SMEs offer improved services and undertake responsible practices to maintain reputation and integrity to retain and attract customers on a continuous basis.

\section{Strategies of Engagement in CSR}

The SMEs have adopted several strategies to engage in CSR in the communities of their location. These strategies reflect the different dimensions or areas of CSR initiatives (Inyang, 2013):

1) Community involvement or development: The relatively local character of SMEs makes it possible for 
employees and owners to be well known in the community. Thus, the SMEs have strong identification with the community which also serves as a major external driver. The SMEs are therefore engaged in community-related activities such as sports, health and education, and other philanthropy giving. Meeting such obligations endures the business to the community.

2) Employee-related initiatives: The employees are very important stakeholders in SMEs engagement in CSR, and with this understanding, the small business operators develop a very fruitful and cordial relationship with the workforce. The main social responsibility issues relating to employees include promotion of employee health and safety, remedial education for disadvantage employees, employee training and development, paying employee adequate reward, and their involvement in decision making. These in turn enhance employee's enthusiasm and commitment to the company. It is worthy to note also that the SMEs offer great employment opportunities in the community and this is considered as socially responsible action.

3) Consumerism: The customers also play a role as drivers in CSR engagement of the SMEs even if it is not at the same scale of large organisations. SMEs have responsibility to their customers by providing quality products and services to enhance the customers' well-being as this can impact positively on their revenues. Consumerism is concerned about honesty in advertising, product safety, reliability and durability of products, fair pricing, and responsiveness to customers' needs. In fact, SMEs are naturally closed to their customers and are able to understand their needs and which they readily satisfy.

4) Environmental initiatives: The SMEs are beginning to show concern for the environment by designing environmentally friendly products or production processes, energy conservation, an efficient use of resources to minimize wastages, reduction in pollution, etc. This marks a humble beginning that is likely to see SMEs undertaking large-scale environmentally responsible practices.

5) Supply chain: The large organizations are putting increasing pressures on SMEs to behave responsibly. These organisations increasingly include environmental and social criteria in their procurement processes, and this has positive influence on CSR behaviour of suppliers. These large organisations encourage their suppliers to adhere to fixed requirements in their business dealings and play a further role in educating the supply chain partners in CSR-related activities. Thus, the SMEs in performing their roles as providers of goods and services to large companies automatically undertake responsible initiatives which impact on the environment and social and human resources issues.

\section{Benefits of Implementation of CSR by SMEs}

Many studies have identified several benefits that SMEs derived from the adoption and implementation of CSR programmes.

Table 1. Benefits of implementation of CSR by SMEs

\begin{tabular}{ll}
\hline Literature/Research Works & Findings: Benefits Highlighted \\
\hline Andreasen, 1996; Sagawa, 2001; Wymer and Samu, 2003 & - Increased sales \\
& - Brand differentiation \\
& - Enhanced brand image \\
& - Improve employee recruitment \\
& - Morale and retention \\
& - Enhanced government relations \\
\hline Risks, 2005 & - Ability to reach new customer segments \\
& - Increase visibility \\
\hline Madden, Scaife and Crissman, 2006 & - Enhanced corporate image \\
& - Thwarting negative publicity \\
\hline Vyakarnam, Bailey, Myers and Burnett, 1997. & - Increased sales \\
& - Building staff morale. \\
& - Building and maintaining client relationships \\
\hline Jenkins, 2006 & - Show concern for staff and their interest. \\
& - Enhanced reputation \\
\hline & - Enhanced professional image \\
\hline & - Increased confidence and loyalty \\
\hline & - Improved image and reputation \\
& - Improved trust and understanding \\
\hline
\end{tabular}




\begin{tabular}{|c|c|}
\hline & $\begin{array}{l}\text { - Better market position } \\
\text { - More business } \\
\text { - Increased employer motivation } \\
\text { - Increased attractiveness to potential recruits } \\
\text { - Cost savings and increased efficiency } \\
\text { - Risk management } \\
\text { - Benefits company culture }\end{array}$ \\
\hline Dzansi, 2011 & $\begin{array}{l}\text { - Community improvement } \\
\text { - Customer satisfaction } \\
\text { - Happy workers } \\
\text { - Employability } \\
\text { - Sales growth } \\
\text { - Profit growth } \\
\text { - Community goodwill } \\
\text { - Employee loyalty } \\
\text { - Motivated workforce }\end{array}$ \\
\hline Santos, 2011 & $\begin{array}{l}\text { - Better reputation } \\
\text { - Higher employee motivation } \\
\text { - Raising quality } \\
\text { - Better productivity }\end{array}$ \\
\hline
\end{tabular}

Source: Author's research.

\section{Constraints and Challenges Associated with Adoption and Implementation of CSR by SMEs}

Several barriers or constraints associated with adoption and implementation of CSR by SMEs have been identified in the emerging literature:

1) The cost of implementing CSR is usually considered too high especially when SMEs lack financial resources and when survival is often the greatest economic imperative.

2) Time constraint affect commitment to CSR initiatives since small business operators are preoccupied with daily administration of the enterprises and with bigger issues.

3) There is limited knowledge among a large spectrum of SMEs about social performance issues.

4) A lack of awareness of the benefits of CSR with no/little understanding of the business case for SMEs.

5) SMEs lack of capacity to collect and analyse useful data in sustainable development.

6) SMEs have no systematic incentives or frameworks to engage with the CSR issues.

7) Lack of information on CSR activities by SMEs and this affect their commitment.

8) The existing CSR tools and guidelines are mainly designed for large business organizations and are of little or no relevance to SMEs.

9) SMEs lack adequate support services to guide and support the adoption and implementation of CSR programmes.

10) The fear of additional regulatory and bureaucratic burdens constrained SMEs from getting involved in CSR initiatives.

\section{Overcoming the Constraints to Implementation}

To overcome these challenges or constraints, the SMEs require adequate resources to provide comprehensive information about the nature of CSR activities and the appropriate strategies and tools to employ to be able to achieve desired results. There is need to have in place formalized tools that go beyond the informal networks. Tools, guidelines and standards tailored to meet the specific needs of the SMEs should be developed since those developed for large organizations are quite inappropriate to handle the concerns of SMEs. The SMEs do look forward for guidance in their efforts to adopt and effectively implement and report on their CSR policies, processes and performances. When there is such support, the small business operators can take their commitment to the next level. Gelbmann (2010) reports about the Austrian CSR Quality Seal directed at SMEs to help them communicate their sustainability performance effectively and display a visible sign for their stakeholders. This seal is helping SMEs to develop a clear picture of their social and environmental performance or conduct. 
The SMEs operators need to be educated on themes related to business ethics, citizenship and responsible practices. Media publicity, attendance at conferences and workshops can help to increase awareness about the core concerns of CSR initiatives. They need adequate training to understand even the concept of CSR, the business case for their engagement and the process of integrating CSR initiatives into their business function. Jenkins (2009:34) notes that "by placing social responsibility at the core of everyday business decisions, CSR becomes less of an 'add-on' and more 'just the way we do things'”.

Government intervention may be necessary even though CSR is voluntary. This would be helpful in providing a level playing field. This could be done through the enactment of appropriate legal framework to encourage CSR through tax policy incentives for CSR practices. The creation of the requisite institutional conditions would help to provide visibility for CSR. It is a welcome development that government creates incentives for SMEs to adopt CSR practices and further build their capacity to effectively implement the programmes.

\section{Conclusion}

Much of the academic literature on CSR, which is concerned with the obligations organisations owe society, tended to concentrate on large corporate organisations. Very little literature is currently available to enhance our understanding about the role engagement of SMEs in CSR. However, the recent understanding about the aggregate impacts of SMEs on economic development of nations has begun to shift the research pendulum. The burgeoning literature has clearly shown that the SMEs are motivated by both the internal and external drivers and influences to undertake CSR along the dimensions of community development, employee-related initiatives, consumerism, environmental management and supply chain.

Despite the benefits derived from this engagement - which ranged from improved community relations, employee loyalty and satisfaction to business growth and profitability - the SMEs faced several challenges to adoption and implementation of CRS initiatives. The major constraints of limited resources, lack of training and support services can readily be overcome through increased resources, training programmes, and development of formalized SMEs-oriented tools to guide adoption and implementation, and government intervention strategies to create incentives and support services for SMEs engagement in CSR.

\section{Acknowledgements}

This paper was presented at the $19^{\text {th }}$ International Business Research Conference organized by the World Business Institute of Australia, held at Monash University, Melbourne, Australia on $19^{\text {th }}-21^{\text {st }}$ November, 2012. The author is grateful to two anonymous reviewers for their comments and the conference participants for their invaluable inputs.

\section{References}

Andreasen, A. R. (1996). Profits for non-profits: Find a corporate partner. Harvard Business Review, 74, 47-59.

Aremu, M. A., \& Adeyemi, S. L. (2010). Small and medium scale enterprise as a survival strategy for employment generation in Nigeria. Journal of Sustainable Development, 4(1), 45-57.

Bowen, H. R. (1953). Social responsibilities of businessman. New York: Harper \& Brothers.

Carroll, A. B. (1979). A three dimensional concept model of corporate social performance. Academy of Management Review, 4, 487-505.

Carroll, A. B. (1999). Corporate social responsibility: Evolution and definitional construct. Business and Society, 38(3), 268-295. http://dx.doi.org/10.1177/000765039903800303

Catalyst Consortium. (2002). What is CSR? Retrieved $30^{\text {th }}$ August 2012 from http://www.rhcatalyst.org.USaid.gov

Darhlsrud, A. (2008). How corporate social responsibility is defined: An analysis of 37 definitions. Corporate Social Responsibility and Environmental Management, 15, 1-13. http://dx.doi.org/10.1002/csr.132

Davis, K., \& Blomstran, R. L. (1975). Business and society: Environment and responsibility (3rd ed.). New York: McGraw-Hill.

Dzansi, D. Y. (2011). Social responsibility of small businesses in a typical rural African setting: Some insights from a South African study. African Journal of Business Management, 5(14), 5710-5723.

Enderle, G. (2004). Global competition and corporate responsibilities of small and medium sized enterprises. Business Ethics: A European Review, 13(1), 51-63. http://dx.doi.org/10.1111/j.1467-8608.2004.00349.x

European Union. (2002). Green paper promoting a European framework for corporate social responsibility. 
Brussels: European Commission.

Fitjar, R. D. (2011). Little big firms? Corporate social responsibility in small business that do not compete against big ones. Business Ethics: A European Review, 20(1), 30-44. http://dx.doi.org/10.1111/j.1467-8608.2010.01610.x

Freisleben, G. (2011). Benefits \& burdens of CRS for SMEs. Financial Executive, October, 53-56.

Gelbmann, U. (2010). Establishing strategic CSR in SMEs: An Austrian CSR Quality Seal to substantiate the strategic CSR performance. Sustainable Development, 18(2), 90-98. http://dx.doi.org/10.1002/sd.448

Hsu, J., \& Cheng, M. (2011). What prompts small and medium enterprises to engage in corporate social responsibility? A study from Taiwan. Corporate social Responsibility and Environmental Management, 19(5), 288-305. http://dx.doi.org/10.1002/csr.276

Industry Canada. (2009). Corporate social responsibility guide project leader. Retrieved 30 August 2012 from http://www.ioc.gc.ca/eic/site/csr-rse.ns/eng/rs00128.html

Inyang, B. J. (2013). Small- and medium-sized enterprises engagement in CSR. In S. O. Idowu, N. Capaldi, L. $\mathrm{Zu} \&$ A. D. Gupta (Eds.), Encyclopedia of Corporate social responsibility (4 vols). Heidelberg: Springer. http://dx.doi.org/10.1007/978-3-642-28036-8_80

Inyang, B. J., Awa, H. O., \& Enuoh, R. O. (2011). CSR-HRM nexus: Defining the role engagement of the human resources professional. International Journal of Business and Social Sciences, 2(5), 118-126.

Jenkins, H. (2006). Small business champions for corporate social responsibility. Journal of Business Ethics, 67(3), 241-256. http://dx.doi.org/10.1007/s10551-006-9182-6

Jenkins, H. (2009). A 'business opportunity' model of corporate social responsibility for small-and medium-sized enterprises. Business Ethics: A European Review, 18(1), 21-33. http://dx.doi.org/10.1111/j.1467-8608.2009.01546.x

Kechiche, A., \& Soparnot, R. (2012). CSR within SMEs: Literature review. International Business Research, 5(7), 97-104. http://dx.doi.org/10.5539/ibr.v5n7p97

Kongolo, M. (2010). Job creation versus job shedding and the role of SMEs in economic development. African Journal of Business Management, 4(11), 2288-2295.

Kusyk, S. M., \& Lozano, J. M. (2007). Corporate responsibility in small and medium-sized enterprises. Corporate Governance, 7(4), 502-515. http://dx.doi.org/10.1108/14720700710820588

Lepontre, J., \& Heene, A. (2006). Investigating the impact of firm size on small business social responsibility: A critical review. Journal of Business Ethics, 67(3), 257-273. http://dx.doi.org/10.1007/s10551-006-9183-5

Luetkenhort, W. (2003). Corporate social responsibility and the development agenda: Should SMEs care? Working paper, No. 13. Vienna: United Nations Industrial Development Organizations.

Lui, H., \& Fong, M. (2010). The corporate social responsibility orientation of Chinese small and medium enterprises. Journal of Business Systems, Governance and Ethics, 5(3), 33-50.

Madden, K., Scaife, W., \& Crissman, K. (2006). How and why small to medium sized enterprises (SMEs) engage with their communities: An Australian study. International Journal of Nonprofit \& Voluntary Sector Marketing, 11, 49-60. http://dx.doi.org/10.1002/nvsm.40

McWilliams, A., Siegal, D. S., \& Wright, D. G. (2006). Guest Editor's Introduction. Corporate social responsibility: Strategic implications. Journal of Management Studies, 43(1), 1-18. http://dx.doi.org/10.1111/j.1467-6486.2006.00580.x

Meehan, J., Meehan, K., \& Richards, A. (2006). Corporate social responsibility: The 3C-SR model. International Journal of Social $\quad$ Economics, $386-398$. http://dx.doi.org/10.1108/03068290610660661

Obalola, M. (2008). Beyond philanthropy: Corporate social responsibility in Nigerian insurance industry. Social Responsibility Journal, 4(4), 538-548. http://dx.doi.org/10.1108/17471110810909939

Oguntade, A., \& Mafimisehi, T. (2011). Contributions of corporate social responsibility to agriculture and rural development in Nigeria. Journal of Sustainable Development in Africa, 13(4), 110-128.

Owualah, S. I. (1999). Tackling youth unemployment through entrepreneurship. International Small Business Journal, 17(3), 49-59. http://dx.doi.org/10.1177/0266242699173003 
Owualah, S. I., \& Obkoh, L. (2007). Tackling youth restiveness in Niger Delta region of Nigeria through entrepreneurship. Paper presented at 2007 International Council of Small Business (ICSB), World Conference, Turku, Finland, June 13-15.

Porter, M. E., \& Kramer, M. R. (2006). Strategy and society: The link between competitive advantage and corporate social responsibility. Harvard Business Review, December, 1-17.

Princic, L. (2003). Engaging small business in corporate social responsibility: A Canadian small business perspective in CSR. Vancouver: Canadian Business for Social Responsibility.

Ricks, J. M. Jr. (2005). An assessment of strategic corporate philanthropy on perceptions of brand equity variables. Journal of Applied Business Research, 7, 121-134.

Russo, A., \& Perrini, F. (2010). Investigating stakeholder theory and social capital: CSR in large and SMEs. Journal of Business Ethics, 91(2), 207-221. http://dx.doi.org/10.1007/s10551-009-0079-z

Safiriyu, A. M., \& Njogo, B. O. (2012). Impact of small and medium scale enterprises in the generation of employment in Lagos State. Kuwait Chapter of Arabian Journal of Business and Management Review, 1(11), 107-141.

Sagawa, S. (2001). New value partnerships: The lessons of Denny's save the children partnership for building high-yielding cross-sector alliances. International Journal of Nonprofit \& Voluntary Sector Marketing, 6, 199-214. http://dx.doi.org/10.1002/nvsm.147

Sahlin-Anderson, K. (2006). Corporate social responsibility: A trend and a moment, but what and for what? Corporate Governance, 6(5), 595-608. http://dx.doi.org/10.1108/14720700610706081

Santos, M. (2011). CSR in SMEs: Strategies, practices, motivations and obstacles. Social Responsibility Journal, 7(3), 490-508. http://dx.doi.org/10.1108/17471111111154581

Sharma, S., Sharma, J., \& Devi, A. (2009). Corporate social responsibility: The key role of human resource management. Business Intelligence Journal, 2(1), 205-213.

Spence, L. J. (2007). CSR and small business in a European policy context: The five 'Cs' of CSR and small business research agenda 2007. Business and society Review, 112(4), 533-552. http://dx.doi.org/10.1111/j.1467-8594.2007.00308.x

Spence, L., \& Lozano, J. F. (2000). Communicating about ethics with small firms: Experiences from the UK and Spain. Journal of Business Ethics, 27(1), 43-53. http://dx.doi.org/10.1023/A:1006417425446

Van Marrewijk, M. (2003). Concepts and definitions of CSR and corporate sustainability: Between agency and communion. Journal Business Ethics, 44(2/3), 95-105. http://dx.doi.org/10.1023/A:1023331212247

Vives, A. (2006). Social and environmental responsibility in small and medium enterprises in Latin America. The Journal of Corporate Citizenship, 21, 39-50.

Vives, A. (2009). Responsible practices in small and medium enterprises (pp. 7-8). Retrieved 20 July 2011 from http://www.competere.com/.../CSR\%20IN2090SMEs\%Handbook\% 20shorter.pdf

Viviers, S., \& Venter, D. J. L. (2007). Corporate social responsibility: A SMME perspective. African Journal of Business Ethics, 2(1), 20-27.

Vyakarnam, S., Bailey, A., Myers, A., \& Burnett, D. (1997). Towards an understanding of ethical behaviour in small firms. Journal of Business Ethics, 16(15), 1625-1636. http://dx.doi.org/10.1023/A:1022452502299

Wood, D. J. (1991). Corporate social responsibility revisited. Academy of Management Review, 16(4), 691-718.

World Business Council for Sustainable Development, WBCSD. (2009). Business role: Corporate social

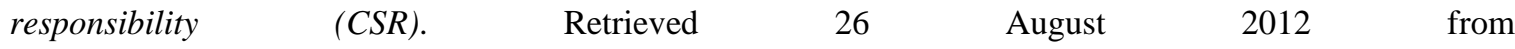
http://www.wbcsd.org/templates/TemplateWBCSD5/layout.asp?type=Menuld-E00

Wymer, W.W. Jr., \& Samu, S. (2003). Dimensions of business and nonprofit collaborative relationships. Journal of Nonprofit \& Public Sector Marketing, 11(1), 3-33. http://dx.doi.org/10.1300/J054v11n01_02 